\title{
HUMAN LEUCOCYTE ANTIGEN PROFILE IN PATIENTS WITH AIDS AND CYTOMEGALOVIRUS RETINITIS WITH AND WITHOUT MACULAR INVOLVEMENT
}

\section{Nivaldo Vieira de Souza1', Eduardo Soares Maia Vieira de Souza², Neifi Hassam Saloum Deghaide ${ }^{3}$, Eduardo Antonio Donadi ${ }^{4}$, Maria de Lourdes Veronese Rodrigues ${ }^{1}$}

\section{ABSTRACT}

Clin Biomed Res. 2015;35(1):14-19

1 Department of Ophthalmology, Otorhinolaringology and Head and Neck Surgery, Ribeirão Preto Medical School, University of São Paulo (FMRP-USP). Ribeirão Preto, SP, Brazil.

2 Department of Surgery, Faculty of Medicine, Federal University of Santa Catarina (UFSC). Florianópolis, SC, Brazil.

3 Laboratory of Molecular Immunology, Ribeirão Preto Medical School University Hospital (HCFMRP). Ribeirão Preto, SP, Brazil.

4 Division of Immunology, Department of Internal Medicine, Ribeirão Preto Medical School, University of São Paulo (FMRPUSP). Ribeirão Preto, SP, Brazil.

Corresponding author:

Maria de Lourdes Veronese Rodrigues

E-mail: mdlvrodr@fmrp.usp.br

Faculdade de Medicina de Ribeirão Preto da Universidade de São Paulo Av. Bandeirantes, 3.900, Monte Alegre. 14040-900, Ribeirão Preto, SP, Brasil.
Introduction: Cytomegalovirus retinitis is one of the ocular manifestations of AIDS. The objective of the present study was to determine possible associations of class I and II HLA antigens and alleles in patients with AIDS and cytomegalovirus retinitis (CMV-R) with and without macular involvement.

Method: The study population consisted of 22 patients with AIDS and CMV-R with macular involvement (Group I), 19 patients with AIDS and CMV-R without macular involvement (Group II), and 202 individuals with negative serology for human immunodeficiency virus (Group III - control). Class I HLA antigens were typed by classical serology. Class II alleles were identified using sequence-specific oligonucleotide primers hybridized with amplified DNA.

Results: HLA-DRB1*14 and HLA-DRB1*10 specificities were more frequent among patients with macular involvement, possibly indicating greater susceptibility to this condition. In contrast, the HLA-B35 antigen may be associated with protection against macular involvement since it was significantly more frequent among patients without this involvement.

Conclusions: The HLA-DRB1*14 and HLA-DRB1*10 alleles may favor the development of CMV-R with macular involvement, whereas the HLA-B35 subtype may be associated with protection against macular involvement.

Keywords: HLA antigens; AIDS-related opportunistic infections; retinal diseases; cytomegalovirus retinitis

Cytomegalovirus (CMV) infections are important within the context of immunosuppression caused by human immunodeficiency virus (HIV-1), with CMV retinitis (CMV-R) representing a severe ocular infection in patients with AIDS, occurring more frequently when the $\mathrm{CD}_{4}{ }^{+}$lymphocyte count is below 50 cells $/ \mathrm{mm}^{3}{ }^{1}$.

There is evidence that the human leukocyte antigen (HLA) system may be associated with patient susceptibility to/protection against CMV-R. Thus the HLA-B44 and HLA-DR7 subtypes ${ }^{2}$ and HLA-B51 ${ }^{3}$ may be associated with susceptibility to CMV-R, and the HLA-B8 antigen may be associated with protection ${ }^{4}$.

The observation of CMV-R cases with and without macular involvement may raise questions about the possibility that HLA subtypes also influence the localization of the lesions. 
Thus, the objective of the present study was to determine possible associations between antigens and class I and II HLA alleles and macular involvement in patients with AIDS and CMV-R.

\section{METHODS}

The present observational study was approved by the Research Ethics Committee of the University Hospital, Faculty of Medicine of Ribeirão Preto, University of São Paulo (Protocol n 25.000-0490) and all patients gave written informed consent to participate.

The reference population for the initial detection of patients with CMV-R consisted of patients with AIDS followed up at the Unit for the Treatment of Infectious Diseases of the University Hospital, Faculty of Medicine of Ribeirão Preto (HCFMRP-USP), recruited from three sectors, i.e., outpatient clinic, day hospital, and ward. Patients referred for ophthalmological care to the Ophthalmology Sector of HCFMRP-USP were later added to the sample.

Forty-one patients (29 men) ranging in age from 23 to 59 years (median: 33 years) participated in the study. Thirty were Caucasoids and 11 were Afro-descendants, according to the classification made by the Registry Sector of HCFMRP-USP.

HIV infection was diagnosed on the basis of the detection of serum antibodies by an immunoenzymatic method (Abbott ${ }^{\circledR}$ Recombinant HIV-1/HIV-2 - IEA, Chicago, IL, USA). Positive results obtained by this method were confirmed by the gelatin particle

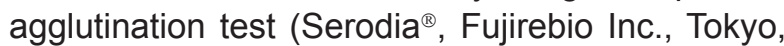
Japan).

Regardless of the group to which he/she belonged, each patient with AIDS diagnosed according to current criteria ${ }^{5}$ was subjected to ophthalmologic examination with emphasis on indirect binocular ophthalmoscopy and had blood samples collected for HLA typing.

The remaining data, including viral load and $\mathrm{CD}_{4}^{+}$cell count, were obtained from the medical records of the patients.

\section{Group I - Patients with AIDS and CMV-R with Macular Involvement}

This group consisted of 22 adult patients with AIDS and CMV-R diagnosed by clinical and laboratory criteria who were studied regardless of whether or not they had started highly active antiretroviral treatment (HAART). They were required to present CMV involvement of the macular region of at least one eye, with consequent low visual acuity $(\mathrm{VA}<0.9 \log \mathrm{MAR})$.

\section{Group II - Patients with AIDS and CMV-R with- out Macular Involvement}

This group consisted of 19 adult patients with AIDS and CMV-R without macular involvement, as determined by ophthalmoscopy (example in figure 1), included in the study according to the same criteria used for Group I patients.

\section{Group III - Controls}

This group consisted of 202 adult individuals with negative HIV-1 serology from the same geographic area and with a similar genetic HLA profile as Group I and II patients. All subjects had negative serology for HIV (organ donors who were healthy until the date of donation) and their DNA is part of the Sample Bank of the Nucleus of Immunogenetic Research (BANPI), approved by the Research Ethics Committee of HCFMRP-USP (Protocol n 7581/2007).

\section{Ophthalmologic Exam}

The ophthalmologic exam of Group I and II patients consisted of the measurement of VA and of indirect binocular ophthalmoscopy followed by retinography.

Snellen optotypes were used to assess VA, with the notations being transformed into logarithmic values - logMar6.

Fundoscopy was performed with an Omega $100^{\circledR}$ indirect ophthalmoscope (Heine, Herrsching, Germany) with a 20-diopter lens (Nikon ${ }^{\circledR}$, Torrance, CA, USA) under mydriasis obtained with $1 \%$ tropicamide (Mydriacyl ${ }^{\circledR}$, Alcon, São Paulo, SP, Brazil). Retinographies were performed using a TRC-50X ${ }^{\circledR}$ retinograph (Topcon, Tokyo, Japan).

For this study, we considered the anatomical macula, a circular area measuring 5 to $6 \mathrm{~mm}$ in diameter located between the superior and inferior temporal vascular arcades and reaching nasally the temporal margin of the optic disk (figure 2).

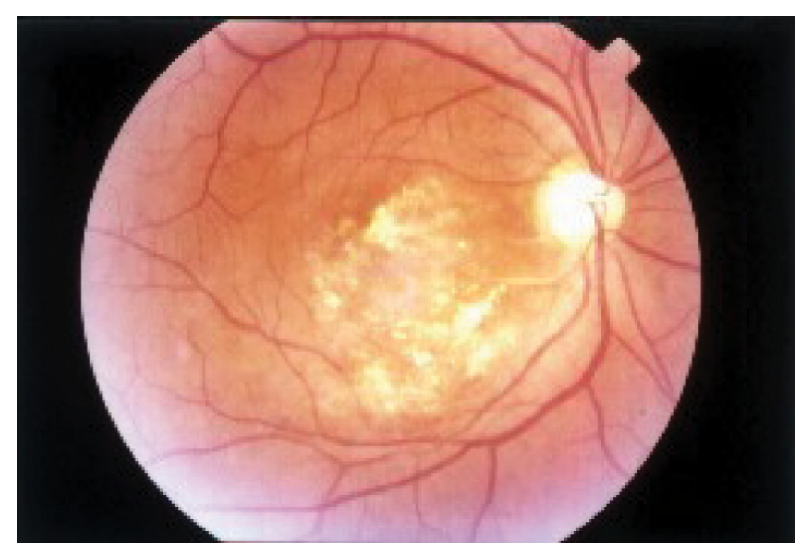

Figure 1: Retinography of patient with CMV-R macular involvement (Patient 2, Group II, right eye). 


\section{Class I HLA Typing}

Peripheral blood lymphocytes were obtained with heparin and separated on a Ficoll-Hypaque density gradient $(1.077 \mathrm{~g} / \mathrm{mL})$.

HLA typing was performed by the complement dependent microlymphotoxicity reaction ${ }^{7}$ using the following HLA antisera: HLA-A (A1, A2, A3, A9, A10, A11, A19, A23, A24, A25, A26, A28, A29, A30, A31, A32, A33, A34, A36, A68, A69); HLA-B (B5, B7, B8, B12, B13, B14, B15, B16, B17, B18, B21, B22, B27,

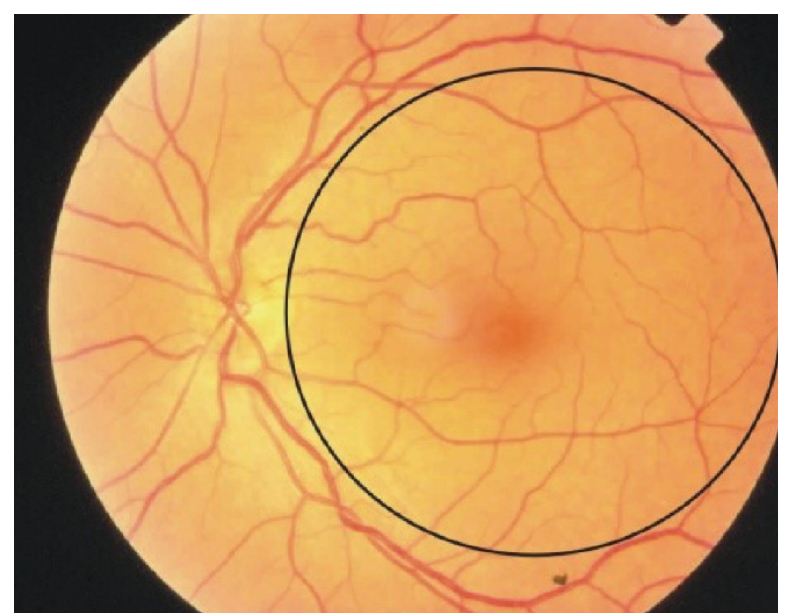

Figure 2: Retinography of the eye fundus and macular area.
B35, B37, B38, B39, B40, B41, B42, B44, B45, B47, B48, B49, B50, B51, B52, B53, B54, B55, B57, B58, $\mathrm{B} 60, \mathrm{~B} 62, \mathrm{~B} 63, \mathrm{~B} 70)$.

\section{Class II HLA Allele Typing (HLA-DRB1, HLA- DRB3, HLA-DRB4, HLA-DRB5 and HLA-DQB1)}

DNA was extracted by the salting-out technique ${ }^{8}$ and the polymerase chain reaction (PCR) was carried out using sequence-specific primers (SSP, Opels, Heildelberg, Germany) ${ }^{9}$. Class II HLA alleles were amplified using a Perkin Elmer 9600 thermocycler (Durham, NC, USA) under the following conditions: 35 cycles at $94^{\circ} \mathrm{C}$ for 30 seconds, at $55^{\circ} \mathrm{C}$ for 1 minute, with an extension at $72{ }^{\circ} \mathrm{C}$ for 1 minute. The PCR products were separated by $2 \%$ agarose gel electrophoresis (Sigma) in Tris-borate and $1 \%$ ethidium bromide.

\section{Statistical Analysis}

The frequency of class I HLA antigens and class II HLA alleles was compared between patients and controls using the two-tailed Fisher test.

\section{RESULTS}

Table 1 shows the VA levels in Group I and Group II participants. Clinical and demographic characteristics of Group I and Group II patients are shown in Table 2.

Table 1: Visual acuity (VA) of Group I and II patients.

\begin{tabular}{cccccc}
\hline \multicolumn{7}{c}{ GROUP I } & & & GROUP II & \\
\hline Patient no. & VA-RE & VA-LE & Patient no. & VA-RE & VA-LE \\
\hline 1 & LP & LP & 1 & 1 & 0.2 \\
2 & FC at $0.15 \mathrm{~m}$ & FC at $2 \mathrm{~m}$ & 2 & 0.7 & 0.0 \\
3 & 0.5 & LP & 3 & 0.1 & 0.3 \\
4 & 0.3 & FC at $10 \mathrm{~cm}$ & 4 & 0.0 & 0.0 \\
5 & 0.7 & FC at $10 \mathrm{~cm}$ & 5 & 0.1 & 0.2 \\
6 & LP & LP & 6 & 0.1 & 0.1 \\
7 & LP & LP & 7 & 0.2 & 0.0 \\
8 & LP & LP & 8 & 0.3 & 1 \\
9 & FCt $1 \mathrm{~m}$ & 0.3 & 9 & 0.8 & 0.0 \\
10 & 0.0 & FC at 3m & 10 & 1 & 0.7 \\
11 & FC at $1 \mathrm{~m}$ & FC at 1.5m & 11 & 1 & 0.0 \\
12 & 0.1 & NIHIL & 12 & 0.1 & 0.3 \\
13 & LP & 0.1 & 13 & 0.0 & 0.3 \\
14 & NIHIL & 0.4 & 14 & 0.1 & 0.7 \\
15 & FC at 2 m & 0.7 & 15 & 0.4 & 0.7 \\
16 & 0.0 & LP & 16 & 0.1 & 0.0 \\
17 & 0.3 & LP & 17 & 0.1 & 0.2 \\
18 & 0.0 & LP & 18 & 0.1 & 0.0 \\
19 & LP & FC at $1 \mathrm{~m}$ & 19 & 0.0 & \\
20 & 0.0 & NIHIL & & & \\
21 & 0.0 & LP & & & \\
22 & 0.0 & NIHIL & & &
\end{tabular}


Table 2: Clinical and demographic characteristics of Group I and Group II patients.

\begin{tabular}{|c|c|c|c|c|c|c|c|c|c|c|c|}
\hline \multicolumn{6}{|c|}{ Group I } & \multicolumn{6}{|c|}{ Group II } \\
\hline $\begin{array}{l}\text { Patient } \\
\text { number }\end{array}$ & $\begin{array}{c}\text { Age } \\
\text { (years) }\end{array}$ & Gender & $\begin{array}{l}\text { Ethnic } \\
\text { Group }\end{array}$ & $\begin{array}{l}\text { Number } \\
\text { of } \\
\text { infections }\end{array}$ & $\begin{array}{l}\mathrm{CD}_{4}^{+} \\
\text {cells/ } \\
\mathrm{mm}^{3}\end{array}$ & $\begin{array}{l}\text { Patient } \\
\text { number }\end{array}$ & $\begin{array}{c}\text { Age } \\
\text { (years) }\end{array}$ & Gender & $\begin{array}{l}\text { Ethnic } \\
\text { Group }\end{array}$ & $\begin{array}{c}\text { Number } \\
\text { of } \\
\text { infections }\end{array}$ & $\begin{array}{c}\mathrm{CD}_{4}^{+} \\
\text {cells/ } \\
\mathrm{mm}^{3}\end{array}$ \\
\hline 1 & 35 & $F$ & $\mathrm{C}$ & 3 & 7 & 1 & 32 & $M$ & $A$ & 2 & 72 \\
\hline 2 & 44 & $M$ & C & 4 & 45 & 2 & 35 & $M$ & $A$ & 2 & 108 \\
\hline 3 & 32 & $M$ & C & 7 & 7 & 3 & 27 & $\mathrm{~F}$ & $A$ & 5 & 24 \\
\hline 4 & 23 & $\mathrm{~F}$ & $A$ & 4 & 157 & 4 & 40 & $M$ & C & 4 & 22 \\
\hline 5 & 40 & $\mathrm{M}$ & C & 4 & 103 & 5 & 34 & $M$ & $A$ & 3 & 42 \\
\hline 6 & 34 & $\mathrm{M}$ & C & 6 & 76 & 6 & 37 & $M$ & C & 3 & 28 \\
\hline 7 & 32 & $M$ & C & 2 & 2 & 7 & 36 & $M$ & C & 4 & 7 \\
\hline 8 & 26 & $\mathrm{~F}$ & C & 4 & 110 & 8 & 32 & $M$ & $\mathrm{C}$ & 5 & 6 \\
\hline 9 & 36 & $\mathrm{M}$ & $A$ & 5 & 72 & 9 & 35 & $M$ & C & 6 & 40 \\
\hline 10 & 52 & $M$ & C & 3 & 42 & 10 & 33 & $F$ & C & 4 & 11 \\
\hline 11 & 31 & $\mathrm{~F}$ & C & 3 & 90 & 11 & 24 & $M$ & C & 4 & 13 \\
\hline 12 & 32 & $\mathrm{M}$ & $A$ & 5 & 47 & 12 & 32 & $M$ & $\mathrm{C}$ & 4 & 5 \\
\hline 13 & 41 & $M$ & $\mathrm{C}$ & 3 & 23 & 13 & 32 & $M$ & $\mathrm{C}$ & 1 & 106 \\
\hline 14 & 59 & $\mathrm{M}$ & C & 2 & 25 & 14 & 34 & $M$ & $A$ & 3 & 13 \\
\hline 15 & 29 & $F$ & C & 5 & 11 & 15 & 30 & $F$ & $A$ & 4 & 8 \\
\hline 16 & 34 & $\mathrm{M}$ & C & 6 & 98 & 16 & 33 & $F$ & C & 6 & 4 \\
\hline 17 & 36 & $M$ & C & 4 & 210 & 17 & 29 & $M$ & C & 4 & 281 \\
\hline 18 & 32 & $F$ & C & 2 & 33 & 18 & 26 & $\mathrm{~F}$ & $A$ & 3 & 66 \\
\hline 19 & 40 & $M$ & C & 4 & 30 & 19 & 33 & $M$ & C & 6 & 32 \\
\hline 20 & 32 & $\mathrm{M}$ & C & 1 & 3 & & & & & & \\
\hline 21 & 39 & $\mathrm{~F}$ & C & 3 & 1 & & & & & & \\
\hline 22 & 33 & $\mathrm{M}$ & A & 4 & 34 & & & & & & \\
\hline
\end{tabular}

$\mathrm{M}=$ male; $\mathrm{F}=$ female; $\mathrm{C}=$ Caucasoid; $\mathrm{A}=$ Afro-descendant.

The frequency of Caucasoid participants was lower in group II than in group I, although the difference was not statistically significant.

The logarithms of the viral loads of Group I patients ranged from 3.96 to 6.44 (median=4.52) and of Group II participants from 3.95 to 6.92 (median=4.76), without differences.

The frequencies of HLA specificities that revealed statistically significant difference between groups are reported in Table 3 as absolute numbers $(\mathrm{N})$ and relative numbers (\%).

The only antigen that differed significantly between the groups with CMV-R was HLA-B35. For this reason, the patients carrying this antigen were evaluated and no statistically significant differences were observed between the two groups regarding variables such as number of opportunistic infections $(p=0.5), C D_{4}^{+}$lymphocyte count $/ \mathrm{mm}^{3}(p=0.7)$ or viral load $(p=0.2)$.

\section{DISCUSSION}

Despite the great advances in AIDS treatment, reducing the frequency of CMV-R, and the medications available for its treatment, this ocular complication is still a cause of reduced quality of life in patients with AIDS.

Compared to the control group, the subtypes HLA-B37, -B48, -B50, -DRB1*14, -DRB1*09, -DRB1*10, and $-\mathrm{DQB} 1{ }^{*} 04$ were more frequent in Group I and the subtypes HLA-A26, -A34, -A36, -B35, -B42, $-B 45$, and $-\mathrm{DQB} 1{ }^{*} 04$ were more frequent in Group II.

However, the only specificities that differed significantly between groups were HLA-DRB1*14 and HLA-DRB1*10, indicating that the presence of these alleles favors the development of CMV-R with macular involvement (Group I x Group III), and HLA-B35, indicating that the presence of this antigen favors the development of CMV chorioretinitis without macular involvement (Group II x Group III). In addition, this last antigen was more frequent among Group II than Group I patients, suggesting that it protects against macular involvement.

It is known that the HLA-B35 antigen is one of the genes associated with the severity of AIDS and with the presence of T.gondii and CMV retinochoroiditis ${ }^{10-14}$, and that $\mathrm{a} \mathrm{CD}_{4}^{+}$lymphocyte count of less than 50 cells $/ \mathrm{mm}^{3}$ is the main factor predisposing to the development of CMV-R, with the risk of these patients 
Table 3: Absolute (N) and relative (\%) numbers of HLA specificities that differed significantly between the groups of patients with AIDS and CMV-R (Group I - n = 22; 44 specificities - with macular involvement; Group II - n = 19; 38 specificities - without macular involvement) and between these groups and the population control (Group III $-\mathrm{n}=202$; 404 specificities).

\begin{tabular}{ccccccc}
\hline \multirow{2}{*}{ Antigen } & \multicolumn{3}{c}{ Group } & \multicolumn{3}{c}{ P Value } \\
\cline { 2 - 7 } & $\begin{array}{c}\text { I } \\
\mathbf{N}(\%)\end{array}$ & $\begin{array}{c}\text { II } \\
\mathbf{N}(\%)\end{array}$ & $\begin{array}{c}\text { III } \\
\mathbf{N}(\%)\end{array}$ & I $\mathbf{x}$ |I & \multirow{2}{*}{ I $\mathbf{x}$ III } & II $\mathbf{x}$ III \\
\hline HLA-B35 & $4(9.1)$ & $11(28.9)$ & $41(10.2)$ & 0.02 & Ns & 0.02 \\
HLA-DRB1*14(6+) & $5(11.4)$ & $1(2.6)$ & $13(3.2)$ & ns & 0.023 & ns \\
HLA-DRB1*10 & $3(6.8)$ & 0 & $5(1.2)$ & ns & 0.034 & ns \\
HLA-DQB1*06 & $3(6.8)$ & $4(10.5)$ & $96(23.8)$ & ns & 0.017 & ns \\
\hline
\end{tabular}

ns= not significant.

being 32.2 times higher than the risk of patients with $\mathrm{CD}^{+}$lymphocyte counts of $51-100 / \mathrm{mm}^{3} 14,15$.

Since all patients with CMV-R studied here had severe AIDS, the frequency of the HLA-B35 antigen was expected to be significantly higher in Groups I and II than in the general population. However, among the participants in this study, the frequency for Group I did not differ from that observed in the general population and was significantly lower compared to Group II.

Looking for a possible explanation, we analyzed the risk factors for the development of CMV-R at the time of diagnosis (number of opportunistic infections, $\mathrm{CD}_{4}^{+}$cell count, and viral load) in Group I and II patients who presented the HLA-B35 antigen and observed that there were no significant differences between groups, although some Group I patients had higher counts than some of Group II patients.

As can also be seen in Table 3, the frequency of the HLA-DQB ${ }^{*} 06$ allele was lower in patients with macular involvement than in controls, indicating a protection against the development of CMV-R.

The only difference that would justify future investigation is the lower frequency of Caucasoids in the group without macular involvement. However, we did not find any literature report showing that African or Afro-descendant patients have lower macular involvement. Conversely, it was reported that genetic markers for hematologic diseases differed, in the northwest region of São Paulo State, according to race ${ }^{16}$.

The main limitation of the present study was the small sample size, although the participants represented about $90 \%$ of HCFMRP-USP patients with CMV-R seen during the total study period, since we only excluded patients whose conditions would have prevented the execution of the necessary exams, or who did not accept to participate in the study.

Thus, we did not detect HLA subtypes that might be considered to be markers of macular involvement or to protect against this involvement. However, the present results suggest that the HLA system may influence the development of the retinal lesions caused by CMV.

\section{Conflicts of interest}

The authors declare no conflicts of interest. Institution where the study was performed: Ribeirão Preto Medical School, University of São Paulo, Brazil.

\section{REFERENCES}

1. Figueiredo JFC, Rodrigues MLV, Souza NV, Romão E, Krieger FTS. Aspectos da aids de interesse para o oftalmologista. Medicina. 1998;31:577-83.

2. Schrier RD, Freeman WR, Wiley CA, McCutchan JA. CMV-specific immune responses and HLA phenotypes of AIDS patients who develop CMV retinitis. Adv Neuroimmunol. 1994;4(3):327-36.

3. Price P, Keane NM, Stone SF, Cheong $\mathrm{KY}$, French MA. MHC haplotypes affect the expression of opportunistic infections in HIV patients. Hum Immunol. 2001;62(2):157-64. http://dx.doi.org/10.1016/S01988859(00)00239-1. PMid:11182226

4. Rodrigues MLV, Figueiredo JFC, Mabtum EA, Deghaide NHS, Souza $\mathrm{NV}$, Romão E, et al. Analysis of class I HLA antigens and class II alleles in Brazilian patients with cytomegalovirus retinitis (CMV-R). In: International Proceedings Division. 12th World AIDS Conference; 1998 June 28-July 3; Geneva, Switzerland. Bologna: Monduzzi Editors; 1998. p. 159-63.
5. Centers for Diseases Control (CDC). 1993 revised classification system for HIV infection and expanded surveillance case definition for AIDS among adolescents and adults. MMWR Recomm Rep. 1993;42:1-13.

6. Bailey IL, Lovie JE. New design principles for visual acuity letter charts. Am J Optom Physiol Opt. 1976;53(11):740-5. http://dx.doi. org/10.1097/00006324-19761100000006. PMid:998716

7. Terasaki PI, McClelland JD. Microdroplet assay of human 
serum cytotoxins. Nature. 1964;204(4962):998-1000. http:// dx.doi.org/10.1038/204998b0. PMid:14248725

8. Miller SA, Dykes DD, Polesky HF. A simple salting out procedure for extracting DNA from human nucleated cells. Nucleic Acids Res. 1988;16(3):1215. http:// dx.doi.org/10.1093/nar/16.3.1215. PMid:3344216

9. Olerup O, Zetterquist H. HLA-DR typing by PCR amplification with sequence-specific primers (PCR-SSP) in 2 hours: an alternative to serological DR typing in clinical practice including donor-recipient matching in cadaveric transplantation. Tissue Antigens. 1992;39(5):225-35. http://dx.doi. org/10.1111/j.1399-0039.1992. tb01940.x. PMid:1357775

10. Just JJ. Genetic predisposition to HIV-1 infection and acquired immune deficiency virus syndrome: a review of the literature examining associations with HLA [corrected]. Hum Immunol.
1995;44(3):156-69. http://dx.doi. org/10.1016/0198-8859(95)00034-8. PMid:8666552

11. Carrington M, Nelson GW, Martin MP, Kissner T, Vlahov D, Goedert JJ, et al. HLA and HIV1: heterozygote advantage and $\mathrm{B}^{\star} 35-\mathrm{CW}^{*} 04$ disadvantage. Science. 1999;283(5408):1748-52. http://dx.doi. org/10.1126/science.283.5408.1748. PMid:10073943

12. Fernandes AP, Gonçalves MA, Zavanella RB, Figueiredo JF, Donadi EA, Rodrigues ML. HLA markers associated with progression to AIDS are also associated with susceptibility to cytomegalovirus retinitis. AIDS. 2003;17(14):2133-6. http://dx.doi. org/10.1097/00002030-20030926000020. PMid:14502022

13. Demarco AL, Rodrigues ML, Figueiredo JF, Deghaide NH, de Menezes MB, Demarco LA, et al. Susceptibility to toxoplasmic retinochoroiditis is associated with HLA alleles reported to be implicated with rapid progression to AIDS. Dis Markers. 2012;33(6):309-12. http:// dx.doi.org/10.1155/2012/612030. PMid:23089920

14. Veronese Rodrigues ML, de Castro Figueiredo JF, Deghaide NH, Romão E, Vieira de Souza N, Donadi EA. Frequency of HLA class 1 and 2 alleles in Brazilian patients with AIDS and cytomegalovirus retinitis. Acta Ophthalmol Scand. 2003;81(5):5146. http://dx.doi.org/10.1034/j.16000420.2003.00098.x. PMid:14510801

15. Spaide RF, Gaissinger A, Podhorzer JR. Risk factors for cotton-wool spots and for cytomegalovirus retinitis in patients with human immunodeficiency virus infection. Ophthalmology. 1995;102(12):1860-4. http://dx.doi. org/10.1016/S0161-6420(95)30783-X. PMid:9098288

16. Zago MA, Costa FF. Hereditary haemoglobin disorders in Brazil. Trans R Soc Trop Med Hyg. 1985;79(3):3858. http://dx.doi.org/10.1016/00359203(85)90389-X. PMid:3898485 